\title{
The Correlation Between Students' Metacognitive Awareness and Reading Comprehension
}

\author{
Tania Mitra Amanda ${ }^{1}$, Merry Prima Dewi ${ }^{2}$ \\ 1 State Islamic Institut of Bukittinggi (IAIN) Bukittinggi, e-mail : taniamitramnd@gmail.com \\ 2 State Islamic Institut of Bukittinggi (IAIN) Bukittinggi, e-mail : merryprimadewi@gmail.com
}

\begin{abstract}
(C)2021 by the authors. Submitted for possible open access publication under the terms and conditions of the Creative Commons Attribution-ShareAlike 4.0 International License-(CC-BY-SA) (https://creativecommons.org/licenses/by-sa/4.0/)

d. $D O I:$ https: //10.30983/mj.v1i1.5123
\end{abstract}

Submission: October 16, $2021 \quad$ Revised: November 30, $2021 \quad$ Published: December 31, 2021

\begin{abstract}
Abstrak
Penelitian ini ditujukan untuk mengidentifikasi bubungan antara kesadaran metakognitif dan pemahaman membaca siswa kelas II SMK Negeri 2 Bukittinggi (SMK Negeri 2 Bukittinggi, Sumatera Barat, Indonesia). Desain penelitian ini adalah penelitian korelasional. Populasi penelitian ini adalab selurub siswa kelas II SMK Negeri 2 Bukittinggi yang berjumlah 544 siswa dan sampel penelitian ini adalab 109 siswa yang dipilih secara acak dari 20\% populasi. Hasil penelitian menemukan babwa ada bubungan antara kesadaran metakognitif dan pemahaman membaca siswa kelas II SMK Negeri 2 Bukittinggi. Koefisien korelasi (rxy) sebesar 0,285 yang berarti korelasi rendah. Jike dibandingkan antara rxy dan rtabel didapatkan babwa 0,285 > 0,05 yang berarti Ha diterima dan Ho ditolak. Disimpulkan bahwa kesadaran metakognitif memiliki korelasi positif terhadap pemahaman membaca siswa. Dengan demikian, jika siswa memiliki kesadaran metakognitif, pemahaman membaca mereka akan meningkat.
\end{abstract}

Kata Kunci: Korelasi, Kesadaran Metakognitif, Pemahaman Membaca.

\begin{abstract}
This research is aimed to identify correlation between students' metacognitive awareness and reading comprehension of the second grade of SMK Negeri 2 Bukittinggi (State Vocational School 2 of Bukittinggi, West Sumatera, Indonesia). The design of this research was correlational research. The research population was all students at the second grade of SMK Negeri 2 Bukittinggi encompassing 544 students and the samples were 109 students who were selected randomly from $20 \%$ of the population. The research found that there was a correlation between students' metacognitive awareness and reading comprehension at the second grade of SMK Negeri 2 Bukittinggi. The correlation coefficient $\left(\mathrm{r}_{\mathrm{xy}}\right)$ is 0,285 which means as low correlation. If it is compared between $\mathrm{r}_{\mathrm{xy}}$ and

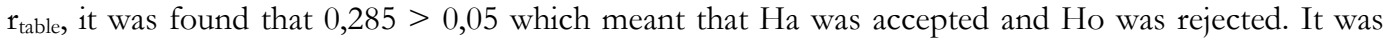
concluded that metacognitive awareness had a positive correlation to students' reading comprehension. Thus, if the students have metacognitive awareness, their reading comprehension will increase.
\end{abstract}

Keywords: Correlation, Metacognitve Awareness, Reading Comprehension

\section{Introduction}

Reading becomes one of the language skills that must be mastered by the language learner to get information from books or texts that is used to enrich their knowledge. Reading is an active process that necessitates attention in order to grasp the meaning of the text (Afdaleni, 2014; Roza \& Khairani, 2019). When the students read a text, they are engaged to construct meaning by combining information from the text with the student's own background knowledge (Syafitri,2018; Sya'ban \& Reflinda, 2021). The goal of teaching reading is to improve students' reading skills so that they can comprehend and efficiently read English texts. The students have to be aware that understanding reading text needs the right and appropriate strategy (Wardah, 2014; Kartawijaya, 2017). When the students apply the right and appropriate strategy, the process of understanding the reading text will be easier (Jaleel, 2016; Septiani, 2021). 
One of the ways to help students to comprehend texts in English is by employing the appropriate strategies by using their metacognitive awareness. Metacognitive awareness is the abilities to reflect on what controls of learning process, knowing what they are learning and how to learn it. By using metacognitive awareness in learning help students to plan strategies and ways of learning and achieving the goals. Metacognition is the kind of one's thinking and the strategies one is using. It helps students be more aware of what they are doing and why they are doing it, as well as how the abilities they are acquiring might be applied differently in different situations. Thus, metacognitive awareness can help students learn to manage their own learning and be aware to every process of their learning.

Metacognitive awareness and reading are decisions we make consciously regarding how students learn to comprehend English texts well. Since metacognitive awareness related to reading, Careell (1998) found that the close relationship between readers' metacognitive awareness and their reading comprehension both their L1 and L2. Metacognitive awareness also helps students to have a strategy and specify goals to determine the meaning of text.

The preliminary research that was conducted in SMK Negeri 2 Bukittinggi on the March $25^{\text {th }}$ 2021 found that the students were still passive in participating in the reading learning activity. They were just silent and there was no enthusiasm in the reading process, but when the teacher gave the exercise related to understanding the text and reading comprehension test, some students could do it well even though it did not meet the criteria of good reading comprehension. In relation to their ability in analyzing their exercise, some students could not analyze the text well. This becomes the indication that the students did not apply yet their metacognitive awareness in reading well at the time.

\section{Method}

This research employs quantitative approach. The quantitative research aims to explain phenomena by gathering numerical data and analyzing it using mathematically based methods in particular statistics. This research also belongs to correlational study which was designed for demonstrating the correlations between two or more variables. The research population was all students at the second grade of SMK Negeri 2 Bukittinggi (State Vocational School 2 of Bukittinggi, West Sumatera, Indonesia) encompassing 544 students. The samples were 109 students who were selected randomly from $20 \%$ of the population. Metacognitive Awareness of Reading Strategy Inventory (MARSI) as proposed by Mohktari and Reichard (2002) and multiple choice tests were used as research instruments as displayed below:

Table 1

Metacognitive Awareness of Reading Strategies Inventory (MARSI)

\begin{tabular}{|ll|}
\hline $\begin{array}{l}\text { Global Reading Strategies } \\
\text { (GLOB) }\end{array}$ & $\begin{array}{l}\text { Generalized, intentional reading strategies aimed at } \\
\text { setting the stage for the reading act. }\end{array}$ \\
\hline $\begin{array}{l}\text { i.e. "Setting purposes for reading", "making } \\
\text { predictions" }\end{array}$ \\
\hline Problem Solving Strategies (PROB) & $\begin{array}{l}\text { Action plans that allow them to navigate through } \\
\text { skillfully. }\end{array}$ \\
\hline i.e. "re-reading", "adjusting reading speed" \\
\hline Support Reading Strategies (SUP) & $\begin{array}{l}\text { Use of outside reference materials } \\
\text { i.e. "taking notes", "translating" }\end{array}$ \\
\hline
\end{tabular}


The table above indicates that MARSI are divided into three categories types, and each type has function in reading. Then, content validity was applied in this research, and the reliability of the test was achieved through try out test, in try out test which was followed by the same students who did not belong to the sample in this research. The data were analyzed through transformed ordinal data into interval data using MSI (Method of Successive Interval).

\section{Results and Discussion}

This part describes the basic information derived from the analysis of each variable through descriptive statistics, prerequisite analysis, and the data analysis using simple and multiple regression. This is displayed in the following table 1 and 2 :

Table 2

Descriptive statistics of Metacognive Awareness (MARSI) and Reading Comprehension test

\begin{tabular}{|llll|}
\hline $\begin{array}{l}\text { Metacognitive } \\
\text { Awareness }\end{array}$ & & $\begin{array}{l}\text { Reading } \\
\text { Comprehension }\end{array}$ \\
\hline $\mathrm{N}$ & 109 & $\mathrm{~N}$ & 109 \\
\hline Mean & 87,26 & Mean & 68,26 \\
\hline Median & 88,00 & Median & 72,00 \\
\hline Mode & 95 & Mode & 64 \\
\hline Std. Deviation & 17,595 & Std. Deviation & 17,957 \\
\hline Minimum & 39 & Minimum & 24 \\
\hline Maximum & 134 & Maximum & 96 \\
\hline Sum & 9511 & Sum & 7440 \\
\hline
\end{tabular}

Table 3

Correlation between Students' Metacognitive and Reading Comprehension

\begin{tabular}{|c|c|c|c|}
\hline & & $\begin{array}{l}\text { Metacognitive } \\
\text { Awareness }\end{array}$ & $\begin{array}{c}\text { Reading } \\
\text { Comprehension }\end{array}$ \\
\hline \multirow{3}{*}{$\begin{array}{l}\text { Metacognitive } \\
\text { Awareness }\end{array}$} & $\begin{array}{l}\text { Pearson } \\
\text { Correlation }\end{array}$ & 1 & $.285^{* *}$ \\
\hline & Sig. (2-tailed) & & .003 \\
\hline & $\mathrm{N}$ & 109 & 109 \\
\hline \multirow{3}{*}{$\begin{array}{l}\text { Reading } \\
\text { Comprehension }\end{array}$} & $\begin{array}{l}\text { Pearson } \\
\text { Correlation }\end{array}$ & $.285^{* *}$ & 1 \\
\hline & Sig. (2-tailed) & .003 & \\
\hline & $\mathrm{N}$ & 109 & 109 \\
\hline
\end{tabular}

The table shows that the correlation coefficient $r=0,285$ which means that there is a positive relationship between students' metacognitive awareness and reading comprehension. Based on the interpretation of Pearson Product Moment Correlation Coefficient between 0,20 - 0,40, there was a low correlation between two variables. The degrees of freedom in this research is $\mathrm{N}-2.109-2=107$. After that, the researcher consults to $\mathrm{r}$-table with significant alpha value $(\mathbf{p})=$ 0,05 and $\mathrm{df}=107$. Based on the $\mathrm{r}$-table, it is obtained 0,1882 , and the researcher has $\mathbf{r}_{\mathrm{xy}}=0,285$ which mean that $r_{x y}$ score is bigger rather than $r_{\text {table }}$ score. Briefly, $\mathrm{Ha}$ is accepted and Ho is rejected which mean that there is a significant correlation between students' metacognitive awareness and reading comprehension. 
The data analysis above indicates that there is the significant correlation between students' metacognitive awareness and reading comprehension of the second grade at SMK Negeri 2 Bukittinggi. Students who develop their metacognitive awareness can be trained to choose, recognizing and arranging the information and problem solving of the reading passage (Mokhtari and Sheorey, 2002. This is line with them, Anderson (2002) argues that the students can think and make conscious decision about the learning process when they have metacognitive ability to select and use appropriately strategy in a given context for a specific purpose. Using metacognitive awareness is essential to promote self-awareness and self-monitoring is to help students become self-sufficient learners who can manage their own learning and learn how to learn for life. Moreover, the students' knowledge of metacognitive reading strategy was significantly influenced by their level of English proficiency (Hacker, 2009; Tavakoli, 2014).

\section{Conclusion}

Although there was a low significant correlation between students' metacognitive awareness and reading comprehension of the second grade in SMK Negeri 2 Bukittinggi, this research proved that students' metacognitive awareness is positively related to reading comprehension. It means that when the students aware of their metacognitive awareness, they can find the effective strategies in reading comprehension.

\section{References}

Anderson, N, J. (2002). The Role of Metacognition i m Seesmd Lamguage.

Carrell, P. L. (1998). SLA and Classroom Instruction: Reading. Annual Review of Applied Linguistics, 9(1988), 223-242. https://doi.org/10.1017/s026719050000091x

Hacker, D. J., Dunlosky, J., Graesser, A. C., Zimmerman, B. J., \& Moylan, A. R. (2009). SelfRegulation from: Handbook of Metacognition in Education Routledge. 11531, 1. https://doi.org/10.4324/9780203876428.ch16

Jaleel, S., \& P., P. (2016). A Study on the Metacognitive Awareness of Secondary School Students. Universal Journal of Educational Research, 4(1), 165-172. https://doi.org/10.13189/ujer.2016.040121

Kartawijaya, S. (2017). Analysis of the Students' Reading Comprehension in. Analysis of the Students' Reading Comprehension in Comprehending Descriptive Text, 2(3), 80-87. http://dx.doi.org/10.22216/jcc.v2i3.2695

Mokhtari, K., \& Reichard, C. A. (2002). Assessing students' Metacognitive Awareness of Reading Strategies. Journal of Educational Psychology, 94(2), 249-259. https://doi.org/10.1037/00220663.94.2.249

Afdaleni, M.Pd., M.Pd (2014). Using Metacognitive Learning Strategy to Improve Reading Comprehension. $40-45$.

Roza, V., \& Khairani, Z. (2019). Students' Attitude Toward Extensive Reading at English Education Study Program in IAIN Bukittinggi. https://doi.org/10.4108/eai.17-10-2019.2289774

Septiani, D., \& Safitri, L. (2021). Improving Students' Reading Comprehension on Procedure 
Text By Using Demonstration Method At Grade X IPA 1 SMAN 1 Candung. Indonesian Journal of Learning Studies, 81-86. https://dmi-journals.org/ijls/article/view/25

Sya'ban, W., \& Reflinda, R. (2021). Guided Reading Approach to Reach Students' Reading Comprehension: A Descriptive Qualitative Research. https://doi.org/10.4108/eai.14-92020.2305687

Syafitri, W. (2018). Problems In Learning Reading (Case Study: Islamic Banking Students of IAIN Bukittinggi). Journal Educative : Journal of Educational Studies, 3(1), 39. https://doi.org/10.30983/educative.v3i1.540

Tavakoli, H. (2014). The Effectiveness of Metacognitive Strategy Awareness in Reading Comprehension: The Case of Iranian University EFL Students. 14(2), 314-336.

Wardah, W. (2014). Metacognitive Reading Strategy Enhancing English Reading Comprehension. At-Turats, 8(1). https://doi.org/10.24260/at-turats.v8i1.107 